\title{
BIOADSORPTION OF CR (VI) IN AQUEOUS SOLUTIONS BY PSEUDOMONAS KOREENSIS IMMOBILIZED IN ALGINATE BEADS
}

\author{
S.G. GARCÍA TORRES, S. CARLOS HERNÁNDEZ \& L. DÍAZ JIMÉNEZ \\ Cinvestav Saltillo, SRNyE. Ramos Arizpe, Coah. México
}

\begin{abstract}
Water pollution by $\mathrm{Cr}$ is challenging due to its high toxicity. Most of chromium is released by industrial processes. Different methods have been developed to remove heavy metals from water, but they are expensive and not efficient for low concentrations. Microorganisms have received attention since they are able to grow in stress conditions. Bacteria living in water bodies near to mining are resistant to heavy metals; then, they have potential for bioadsorption applications. The purpose of this work was to isolate a microorganism tolerant to $\mathrm{Cr}$ from water bodies near to a mining zone. The isolated, Pseudomonas koreensis, was immobilized in alginate beads and its efficiency to remove $\mathrm{Cr}$ from water was evaluated. For isolation, serial dilution of samples was conducted; microorganisms were cultured in EMB, MacConkey and Mannitol salt agar and incubated at $30-35^{\circ} \mathrm{C}$ for $24 \mathrm{~h}$. The dominant colonies were replanted in nutrient agar supplemented with chromium and they were incubated at $30-35^{\circ} \mathrm{C}$ until growth evidence. Species identification was done according to Bergey's Manual and by $16 \mathrm{~S}$ rDNA sequencing. Alginate beads were prepared by slow continuous deposition method. Isolated bacteria were set in batch reactors together with alginate beads and nutrient medium to promote microorganism immobilization. The biofilm presence was confirmed through SEM. A random experimental design was used to determine the best amount of adsorbent in lab scale batch reactors. The concentration was taken as variable considering 15,25 and $40 \mathrm{~g}$. Temperature, $\mathrm{pH}$, stirring and concentration of $\mathrm{Cr}$ (VI) were fixed at $30^{\circ} \mathrm{C}, 6.6,150 \mathrm{rpm}$ and $10 \mathrm{ppm}$, respectively. Samples from 0 to $56 \mathrm{~h}$ were taken. A variance analysis was performed. Chromium removal of $97 \%$ at $32 \mathrm{~h}$ was reached. Significative difference was observed related to adsorbent concentration and time. The best results correspond to $40 \mathrm{~g}$ of adsorbent. Keywords: Heavy metal adsorption, biofilm, bioremediation, water management, microorganisms isolation.
\end{abstract}

\section{INTRODUCTION}

The increase in industrialization and the negligence in the use of natural resources contribute to the release of heavy metals into aquifers. These elements represent a threat to health and the environment due to their toxicity, cumulative properties, persistence and immutable quality [1].

In recent years, the availability of water has decreased; in addition, contamination by heavy metals is a serious problem since these can remain a long time in water and in small quantities can cause damage to health. Chromium is considered one of the most toxic heavy metals [2]. Its main risks include carcinogenic potential [3], causing damage to the erythrocyte membranes [4], generating oxidative stress, causing DNA damage, cellular apoptosis and altered gene expression [4].

Due to the increase in water pollution, as well as the imbalance of aquatic ecosystems, more attention has been given to ecological measures, since one of the current challenges is to obtain safe and economical drinking water [1].

In this context, bioremediation is a promising alternative for the treatment of water with a low concentration of metals [5]. Among the advantages of bioremediation is that it is easy to implement. it is free of secondary contamination and have low costs [6]. Pseudomonas is one of the most used bacteria for bioremediation since it is adaptable to different environments. This genus is of great importance in wastewater treatment processes due to its high 
capacity to biodegrade many organic compounds [3]. Some species of Pseudomonas have been studied for chromium biosorption (P. putida, P. mendocina and P. aeruginosa) [7-8]. $P$. aeruginosa has shown a high degree of multiple resistance to heavy metals [7].

On the other side, it is known that commonly in polluted areas by effluents from mining occur heavy metal tolerant microorganisms. In Mexico, the largest gold mine in America is located in Mazapil, Zacatecas [9]. Then, it is feasible to find bacteria adapted to this environment which could be useful to remove heavy metals from water, such as chromium.

Some of the disadvantages of the use of microbial biomass in suspension include its particle size, its low mechanical resistance and the complexity in separating the biomass from the effluent. For this reason, a wide variety of inert materials are used as support for microorganisms which allow their immobilization through a biofilm formation [10]. Biofilms improve the adsorption properties of the support, inducing greater resistance to metals and allow an easy separation of biomass from the substrate [11]. The materials evaluated for the immobilization of microbial biomass are agar, cellulose, alginates, silicate, among others [12-15]. Alginate stands out for its properties as biocompatibility and hydrophilicity, as well as being considered a non-toxic substance [16].

The goal of this work was to isolate a chromium tolerant microorganism from a natural watercourse near to a mining area. The isolated microorganism was immobilized in alginate beads and its ability in $\mathrm{Cr}$ removal from water solution was evaluated.

\section{MATERIALS AND METHODS}

\subsection{Water sampling, bacteria isolation and resistance evaluation}

The water samples were taken from a watercourse (Arroyo Grande) and from a spring (Las Goteras) located in Mazapil, Zacatecas, Mexico (23 $41^{\prime}, 25^{\circ} 04^{\prime} / 101^{\circ} 11^{\prime}$ and $\left.102^{\circ} 41^{\prime}\right)$. The town is near to deposits of zinc, gold, silver, copper, mercury, phosphorite, limestone, lulita, calcite, onyx and marble. Water samples were kept at $4{ }^{\circ} \mathrm{C}$ in a dark environment and all analyses were performed within $24 \mathrm{~h}$, according to the Standard Methods for Examination of Water and Wastewater [17]. The identification of metal ions was performed by using a Thermo Model iCE 3000 atomic absorption spectrometer. Water samples were filtered, digested with $\mathrm{HNO}_{3}$, and analysed directly to determine metals concentration, according to the standard NMX-AA-051-SCFI-2001 [18].

For bacteria isolation, a serial dilution from a saline solution of $0.85 \%$ (10-1 to $10-4)$ was conducted on the collected samples. After that, the microorganisms were cultured by duplicate in Nutrient agar, EMB, MacConkey and Mannitol salt agar. Plates were incubated at $30-35^{\circ} \mathrm{C}$ for $24 \mathrm{~h}$ and then microorganism count was performed. Dominant colonies were replanted in a nutrient agar supplemented with heavy metals solutions; they were incubated at $30-3{ }^{\circ} \mathrm{C}$ until detect bacterial growth. For the molecular identification of bacteria, five isolates were chosen among those with the highest metal tolerance. The molecular identification was carried out by $16 \mathrm{~S}$ rDNA sequencing.

\subsection{Biofilter preparation}

\subsubsection{Synthesis of alginate beads}

Alginate beads were elaborated by coprecipitation following the methodology reported by Calero et al. [19]. Briefly, an alginate solution (3 g / $200 \mathrm{~mL})$ was placed in a separation funnel (which was previously conditioned with a micropipette nozzle at the end of the tip of 
the funnel) and a drip was started on a calcium chloride solution ( $3 \mathrm{~g} / 200 \mathrm{~mL})$, in constant magnetic stirring. Finally, the beads were washed 3 times with distilled water.

\subsubsection{Immobilization of $P$. koreensis on alginate beads}

For biofilm formation, $50 \mathrm{~mL}$ of Cetrimide broth ( $17 \mathrm{~g}$ Cetrimide agar / L) previously inoculated with P. koreensis $(24 \mathrm{~h})$ and $5 \mathrm{~g}$ of calcium alginate beads were mixed. The mixture was incubated at $30^{\circ} \mathrm{C}$ with orbital shaking at $150 \mathrm{rpm}$ for $24 \mathrm{~h}$. The formation of the microbial biofilm was confirmed by Scanning Electron Microscopy (SEM): the samples were prepared with a fixative of $2 \%$ formaldehyde and $70 \%$ ethanol for $18 \mathrm{~h}$, they were subsequently dehydrated in gradients of ascending ethanol: $70 \%, 80 \%$ and $95 \%$.

\subsection{Biosorption tests}

The Cr (VI) bioadsorption tests were carried out in $250 \mathrm{~mL}$ reactors. The $\mathrm{pH}$ of the solution was adjusted to 6.6 with a phosphate buffer $(50 \mathrm{Mm})$, and kept in soft agitation: $100 \mathrm{rpm}$ at $30{ }^{\circ} \mathrm{C}$. The contaminant concentration of $\mathrm{Cr}$ (VI) was $10 \mathrm{ppm}$, which was prepared from a stock solution of $1000 \mathrm{ppm}\left(2828 \mathrm{~g}\right.$ of $\left.\mathrm{K}_{2} \mathrm{Cr}_{2} \mathrm{O}_{7} \mathrm{~L}^{-1}\right)$ [2]. The concentrations of bioadsorbent were 15,25 and $40 \mathrm{~g}$, and the reaction volume was $150 \mathrm{~mL}$. The final concentration of metal was determined by atomic absorption spectrometry (AAS) (ICE 3000 SERIES AA SPECTOMETER). Samples were taken at 0, 4, 8, 24 and $32 \mathrm{~h}$ [2, 20-22]. The experiments were carried out by triplicate.

\section{RESULTS AND DISCUSSION}

\subsection{Isolation of $\mathrm{Cr}$ tolerant microorganism}

From bacterial isolation of the collected samples, a multi-resistant bacterium to $\mathrm{Zn}, \mathrm{Ag}, \mathrm{Hg}$ and Co with MIC of 2500, 2500, 85, 105 ppm, respectively, was detected. In addition, this bacterium exhibited intermediate and susceptible responses to $\mathrm{Cr}$. The molecular identification of this bacterium by $16 \mathrm{~S}$ rDNA indicated that it is a Pseudomonas koreensis.

Pseudomonas was the most tolerant to all metals tested, showing an increase in its growth compared to the culture without heavy metals. This was probably due to synergetic effects in the enzymatic catalysis; as the metal concentration increase its toxicity, the stimulating effect decreases, and the system is eventually inhibited [23]. The resistance of this microorganism to metals is probably related to the incorporation of those elements to cytoplasm, once they bind to specific metallothioneins [24-25]. Since P. koreensis is a Gram-negative bacterium, it has a higher resistance to the toxic effects of heavy metals due to its cellular wall, which hinders their incorporation into inner cells [24]. These significant differences in the resistance to heavy metals could be related to variances in the isolation site and to adaptation mechanisms developed by bacteria. Other studies reveal a relationship in tolerance to $\mathrm{Zn}, \mathrm{Cr}$, and $\mathrm{Cu}$ because they are used as micronutrients for different metabolic pathways and tend to bioaccumulate when they exceed certain levels close to MIC [26-27]; this could explain the increase growth for all bacteria in presence of these metals.

\subsection{Alginate beads}

Rounded, soft and clear spheres of alginate were obtained by using a nozzle of 1 to $10 \mathrm{~mL}$ (blue tip). $65 \mathrm{~g}$ of alginate beads were obtained (wet weight); the average diameter of these beads was $3 \mathrm{~mm}$. Fig. 1 shows representative sample of the obtained alginate beads. 


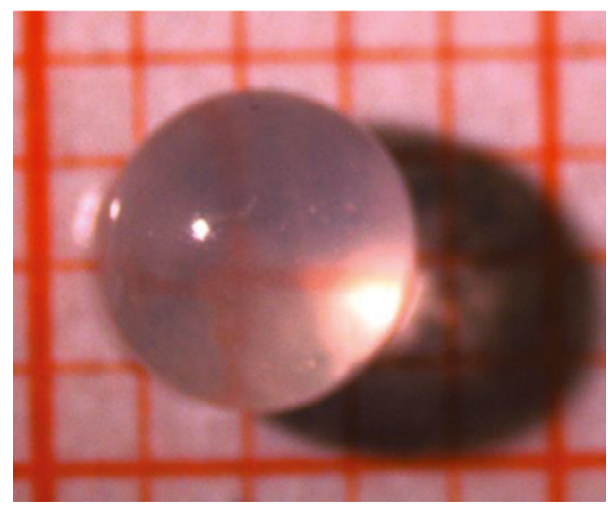

Figure 1: Alginate bead.

\subsection{Microorganisms immobilization}

The viability of the system is verified by microscopy. A sample was taken at the end of the bacteria growth experiment and a gram stain was performed. As shown in Fig. 2, gramnegative bacillus was detected; this bacillus is characteristic of Pseudomonas.

Regarding the adhesion of bacteria to the support, representative samples of alginate beads were taken from the immobilization system at 8,12 and $24 \mathrm{~h}$ to be analyzed. For comparative purposes, a sample of virgin beads was also evaluated. The obtained results are presented in Figs. 3-6.

The micrograph corresponding to the alginate beads sampled at $8 \mathrm{~h}$ shows the adhesion of P. koreensis. It is possible to observe microorganism colonies randomly dispersed (Fig. 3). The analysis of the micrographs also reveals the presence of cellular aggregates, hollows and

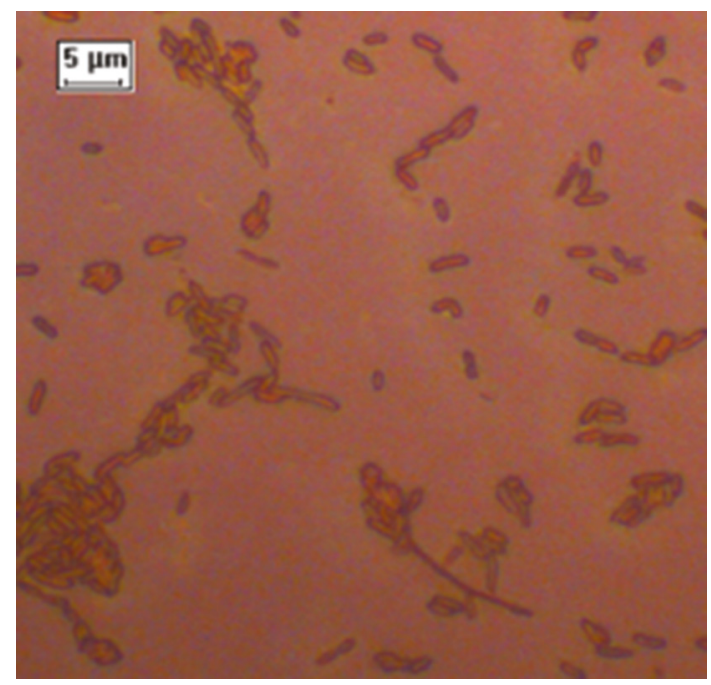

Figure 2: Gram stain of an aliquot of the immobilization medium of $P$. koreensis observed in a petrographic microscope at 40x. 


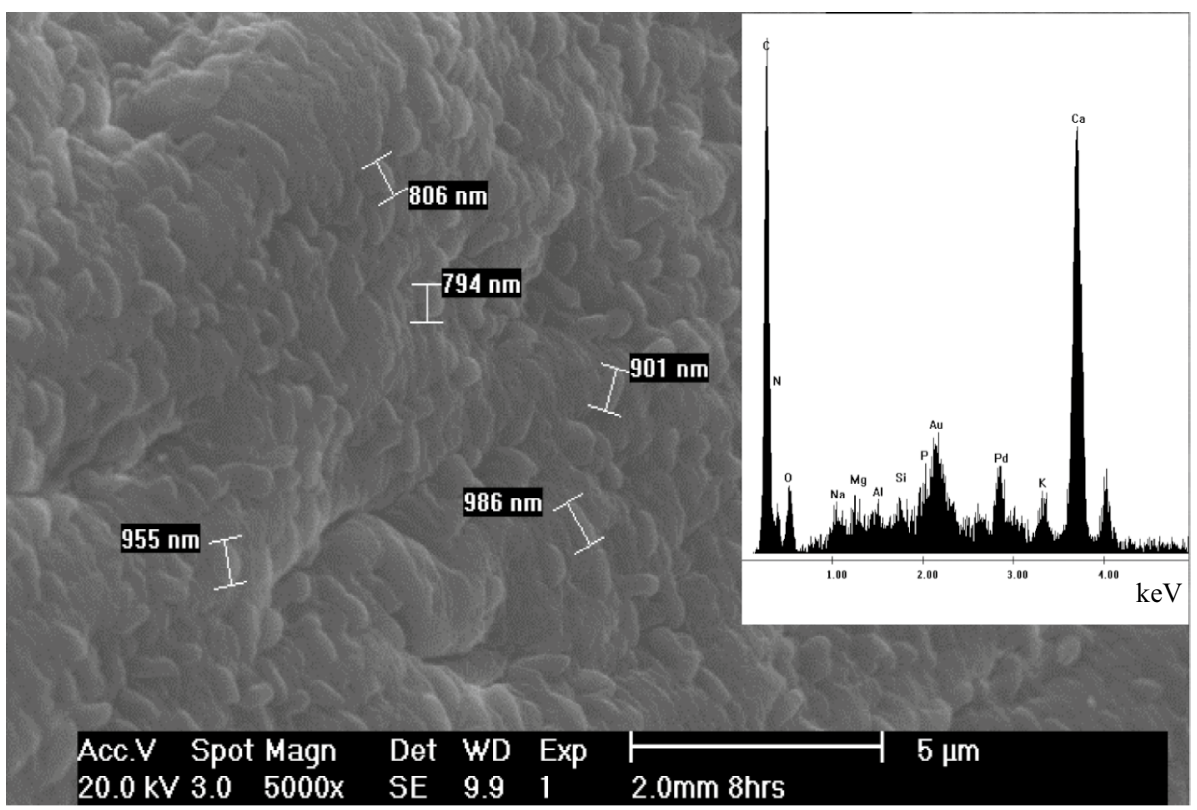

Figure 3: Micrography and EDS analysis of immobilized Pseudomonas koreensis on alginate beads grown during $8 \mathrm{~h}$.

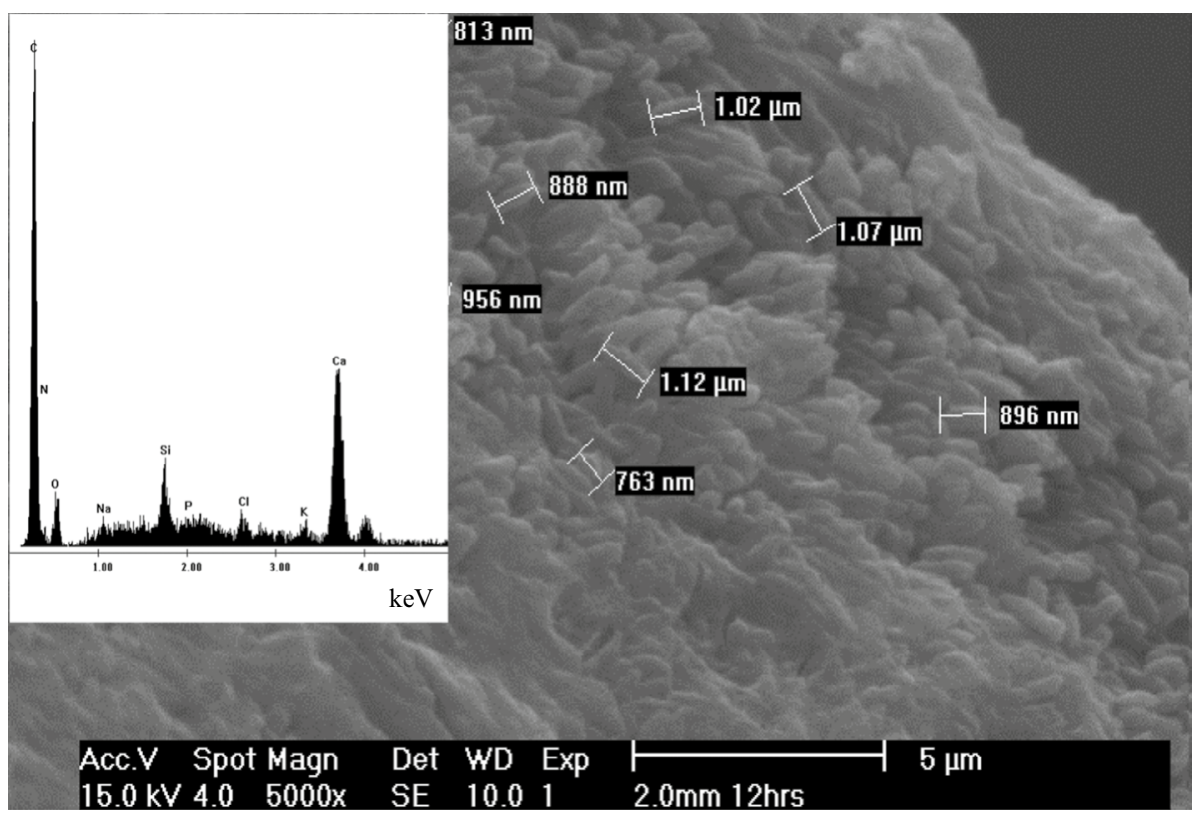

Figure 4: Micrography and EDS analysis of immobilized Pseudomonas koreensis on alginate beads grown during $12 \mathrm{~h}$. 


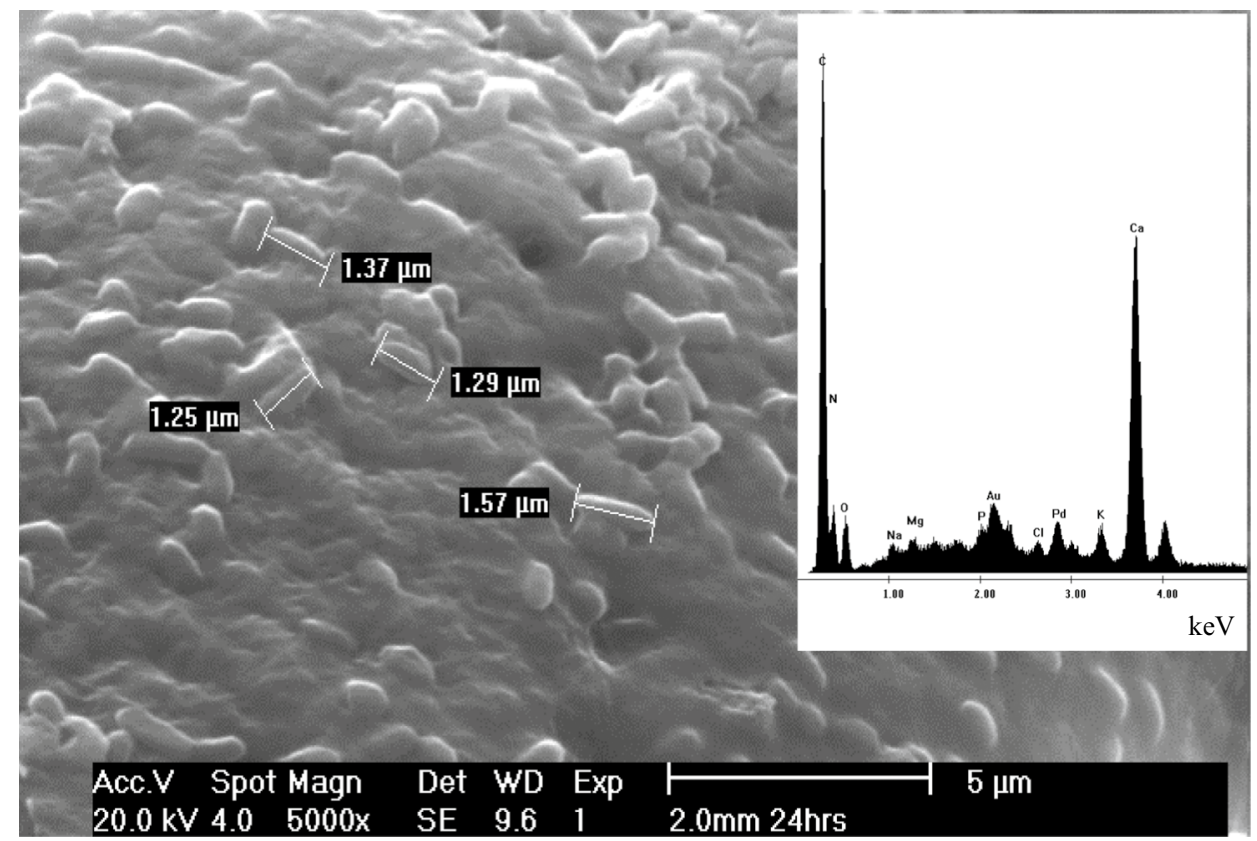

Figure 5: Micrography and EDS analysis of immobilized Pseudomonas koreensis on alginate beads grown during $24 \mathrm{~h}$.

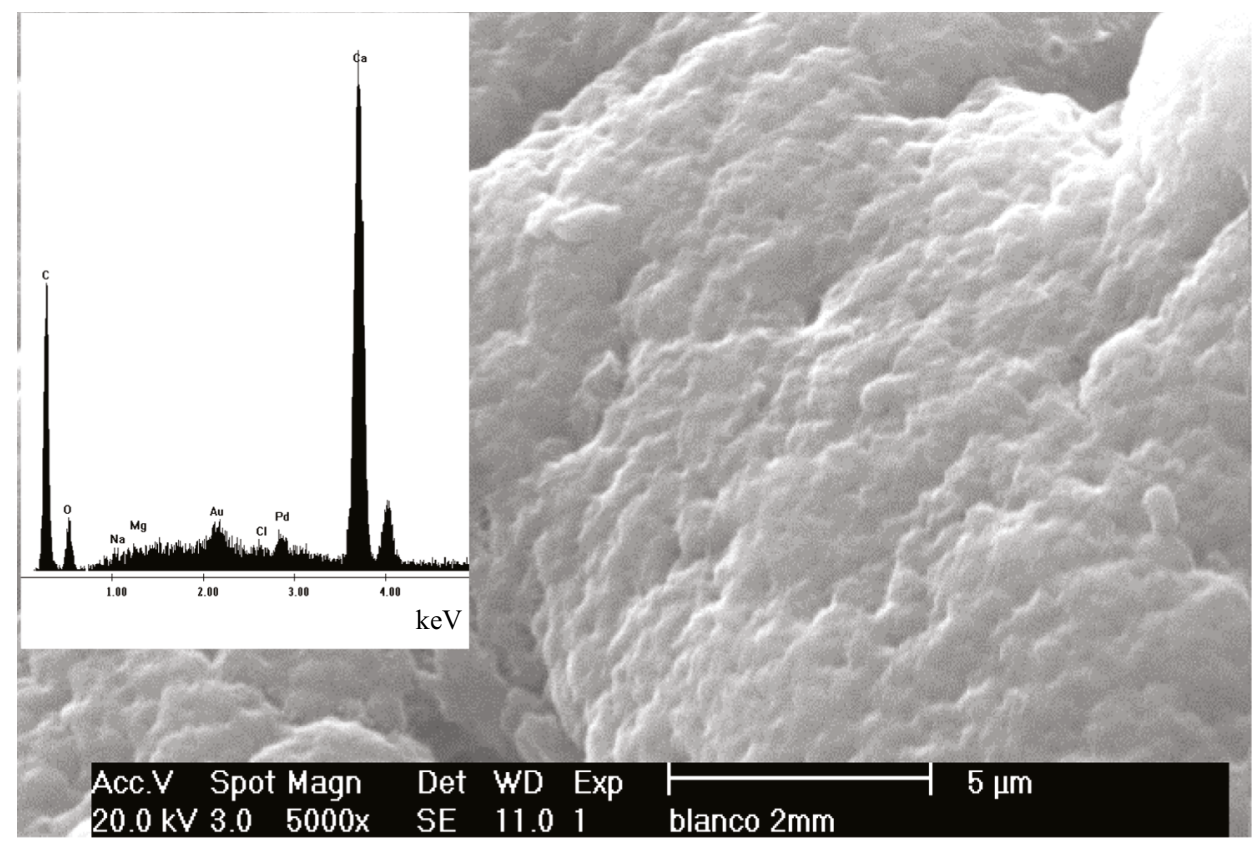

Figure 6: Micrography and EDS analysis of virgin beads. 
biomass embedded in the alginate matrix, of approximately $1 \mu \mathrm{m}$ in length, which agrees with the morphology of $P$. koreensis. This was confirmed by means of EDS, since there are elements characteristic of the prokaryotic bacterium wall (F, N, K). None of the aforementioned characteristics were observed in the virgin beads (Fig. 6).

The observed morphology is similar to that reported by Mangwani; the authors studied the immobilization of $P$. mendocina on glass. In their study, using SEM they verified the presence of a biofilm conformed by bacillar aggregates [28].

\subsection{Biosorption of $\mathrm{Cr}$ in batch assays}

Data obtained from the experiments were analyzed using the software STATISTICA 7.0, a factor analysis with $95 \%$ confidence was considered. Table 1 presents the results of the analysis of variance with the associated variability of the Time and Bioadsorbent dose factors and their interactions. The effect of each factor is defined as the response produced by a change in the level of the factor. All the terms were statistically significant since they have $p$-values lower than 0.05 (95\% confidence level).

It is observed that time and bioadsorbent concentration, as well as their interactions, influence the bioadsorption of $\mathrm{Cr}(\mathrm{VI})$. Since there are significant differences between the treatments and the reference, the results are analyzed by Fisher's test to determine which of the treatments are different from each other. Fisher's test is useful to compare two categorical variables and find if there are significant differences in each of the treatments.

The Fisher test was carried out in the software STATISTICA 7.0 (Table 2). It is shown that the best treatments correspond to 32,48 and $56 \mathrm{~h}$, with a bioadsorbent concentration of $40 \mathrm{~g}$. No significant differences were found between them considering a $95 \%$ confidence. Then, it is determined that the best treatment is $40 \mathrm{~g}$ of bioadsorbent at $32 \mathrm{~h}$, since there are no significant differences if the time is increased.

The $\mathrm{Cr}$ adsorption kinetics of $P$. koreensis is presented in Fig. 7. The parameters used were $\mathrm{pH}$ 6.6, temperature $30{ }^{\circ} \mathrm{C}$, initial concentration of $\mathrm{Cr}$ (VI) $10 \mathrm{ppm}$ and biosorbent dosage $120 \mathrm{~g} / \mathrm{L}$ (wet weight). An adsorption efficiency of $97 \%$ is obtained at $32 \mathrm{~h}$. This percentage of adsorption agrees the reported for $\mathrm{Pb}$ (II) adsorption using Sargassum filipendula [29]; in that work a removal efficiency of $96 \%$ was reached. In another study, the removal percentage of $\mathrm{Cu}$ (II) was $80 \%$ at four days, considering an initial concentration of $200 \mathrm{ppm}$, using as adsorbent a microalgae/bacteria system [30].

Table 1: ANOVA for time and bioadsorbent dose.

\begin{tabular}{lrrrrc}
\hline Factor & Sum of squares & d.f. & Mean square & F value & $\begin{array}{c}p \text {-value } \\
\text { Prob }>\text { F }\end{array}$ \\
\hline Interception & 6658.556 & 1 & 6658.556 & 6749.469 & 0.00 \\
Time (h) & 312.501 & 5 & 62.500 & 63.354 & 0.00 \\
Bioadsorbent (g) & 487.709 & 3 & 162.570 & 164.789 & 0.00 \\
Time* bioadsorbent & 665.856 & 15 & 44.390 & 44.996 & 0.00 \\
Error & 47.353 & 48 & 0.987 & & \\
\hline
\end{tabular}


Table 2: Fisher test.

\begin{tabular}{|c|c|c|c|c|c|c|c|c|c|c|c|c|c|c|}
\hline Time (h) & Bioadsorbent (g) & $\begin{array}{l}\text { Cr VI } \\
(\mathrm{ppm})\end{array}$ & 1 & 2 & 3 & 4 & 5 & 6 & 7 & 8 & 9 & 10 & 11 & 12 \\
\hline 32 & 40 & 0.36 & $*$ & & & & & & & & & & & \\
\hline 48 & 40 & 0.64 & $*$ & & & & & & & & & & & \\
\hline 56 & 40 & 1.85 & $*$ & & & & & & & & & & & \\
\hline 48 & 25 & 3.82 & & $*$ & & & & & & & & & & \\
\hline 32 & 25 & 4.03 & & $*$ & & & & & & & & & & \\
\hline 56 & 25 & 5.88 & & & $*$ & & & & & & & & & \\
\hline 56 & 15 & 8.02 & & & & $*$ & & & & & & & & \\
\hline 32 & 0 & 9.64 & & & & $*$ & $*$ & & & & & & & \\
\hline 24 & 40 & 9.69 & & & & & $*$ & & & & & & & \\
\hline 24 & 25 & 9.97 & & & & & $*$ & & & & & & & \\
\hline 48 & 0 & 10.32 & & & & & $*$ & $*$ & & & & & & \\
\hline 8 & 0 & 10.97 & & & & & $*$ & $*$ & $*$ & & & & & \\
\hline 24 & 0 & 11.07 & & & & & $*$ & $*$ & $*$ & & & & & \\
\hline 8 & 40 & 11.24 & & & & & $*$ & $*$ & $*$ & & & & & \\
\hline 24 & 15 & 11.61 & & & & & & $*$ & $*$ & $*$ & & & & \\
\hline 8 & 25 & 11.64 & & & & & & $*$ & $*$ & $*$ & & & & \\
\hline 8 & 15 & 11.91 & & & & & & $*$ & $*$ & $*$ & $*$ & & & \\
\hline 0 & 0 & 12.15 & & & & & & & $*$ & $*$ & $*$ & $*$ & & \\
\hline 0 & 15 & 12.29 & & & & & & & $*$ & $*$ & $*$ & $*$ & & \\
\hline 0 & 40 & 13.08 & & & & & & & & $*$ & $*$ & $*$ & & \\
\hline 0 & 25 & 13.37 & & & & & & & & & $*$ & $*$ & & \\
\hline 48 & 15 & 13.77 & & & & & & & & & & $*$ & $*$ & \\
\hline 56 & 0 & 15.32 & & & & & & & & & & & $*$ & \\
\hline 32 & 15 & 18.04 & & & & & & & & & & & & $*$ \\
\hline
\end{tabular}

\section{CONCLUSION}

Immobilization of $P$. koreensis was corroborated by SEM and EDS analysis. A significant difference was observed regarding the adsorbent concentration and time. The best result was $97 \% \mathrm{Cr}(\mathrm{VI})$ removal at $32 \mathrm{~h}$, which correspond to $40 \mathrm{~g}$ of adsorbent. P. koreensis seems to be an adequate biosorbent material of heavy metals; this is a possible alternative to minimize the problem of water pollution. 


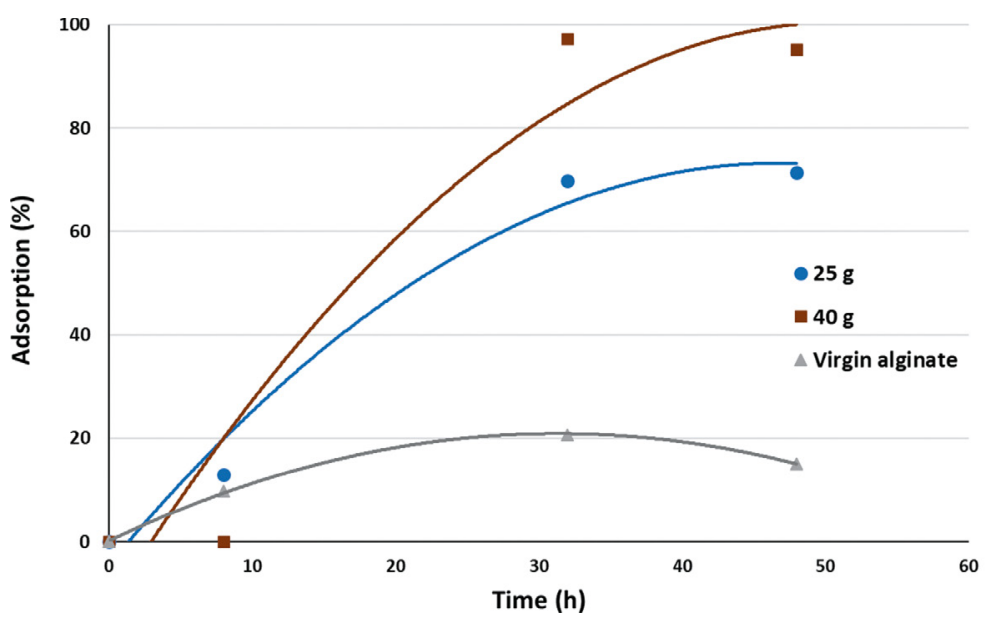

Figure 7: Adsorption of Cr (VI) by P. koreensis immobilized on alginate beads.

\section{REFERENCES}

[1] Gururajan, K. \& Belur, P.D., Screening and selection of indigenous metal tolerant fungal isolates for heavy metal removal. Environmental Technology Innovation, 9, pp. 91-99, 2018.

[2] Majumder, S., Gangadhar, G., Raghuvanshi, S. \& Gupta, S., Biofilter column for removal of divalent copper from aqueous solutions: Performance evaluation and kinetic modeling. Journal Water Processing Engineering, 6, pp. 136-143, 2015.

[3] Sumathi, K.M.S., Mahimairaja, S. \& Naidu, R., Use of low-cost biological wastes and vermiculite for removal of chromium from tannery effluent. Bioresource Technology, 96(3), pp. 309-316, 2005.

[4] Suwalsky, M., Castro, R.,Villena, F. \& Sotomayor, C.P., Cr(III) exerts stronger structural effects than $\mathrm{Cr}(\mathrm{VI})$ on the human erythrocyte membrane and molecular models. Journal of Inorganic Biochemistry, 102(4), pp. 842-849, 2008.

[5] Mclean, J. \& Beveridge, T.J., Chromate Reduction by a Pseudomonad Isolated from a Site Contaminated with Chromated Copper Arsenate Chromate Reduction by a Pseudomonad Isolated from a Site Contaminated with Chromated Copper Arsenate Downloaded from http://aem.asm.org/ on February 7 , 2. Society, 67(3), pp. 1076-1084, 2001.

[6] Mack, C., Wilhelmi, B., Duncan, J.R. \& Burgess, J.E., Biosorption of precious metals. Biotechnology Advances, 25(3), pp. 264-271, 2007.

[7] Mendoza-Hernández, J.C. et al., Biosorción de cromo, arsénico y plomo de soluciones acuosas por cultivos bacterianos en suspensión. Revista Latinoamericana el Ambient y las Ciencias, 1(2), pp. 67-73, 2010.

[8] Mondal, M. et al., Multi-metal resistance and plant growth promotion potential of a wastewater bacterium Pseudomonas aeruginosa and its synergistic benefits. Environmental Geochemistry and Health, 39(6), pp. 1583-1593, 2017.

[9] GoldCorp Inc., Peñasquito - Overview \& Operating Highlights. 2017.

[10] Cañizares, R.O., Biosorción de metales pesados mediante el uso de biomasa microbiana. Revista Latinoamericana Microbiology, 42(3), pp. 131-143, 2000. 
[11] Singh, R., Paul, D. \& Jain, R.K., Biofilms: implications in bioremediation. Trends Microbiology, 14(9), pp. 389-397, 2006.

[12] Vazquez, L. et al., Immobilized microorganisms in the reduction of ethyl benzoylacetate. Tetrahedron Letter, 50(52), pp. 7362-7364, 2009.

[13] Boeris, P.S., Liffourrena, A.S. \& Lucchesi G.I., Aluminum biosorption using non-viable biomass of Pseudomonas putida immobilized in agar-agar: Performance in batch and in fixed-bed column. Environnement Technology Innovation, 11, pp. 105-115, 2018.

[14] Bagde, P. \& Vigneshwaran, N., Improving the stability of bacteriocin extracted from Enterococcus faecium by immobilization onto cellulose nanocrystals. Carbohydrate Polymers, 209, no. October 2018, pp. 172-180, 2019.

[15] Muñoz, A.J., Espínola, F. \& Ruiz, E. Removal of $\mathrm{Pb}(\mathrm{II})$ in a packed-bed column by a Klebsiella sp. 3S1 biofilm supported on porous ceramic Raschig rings. Journal of Industrial and Engineering Chemistry, 40, pp. 118-127, 2016.

[16] Munagapati, V.S. \& Kim, D.S., Equilibrium isotherms, kinetics, and thermodynamics studies for congo red adsorption using calcium alginate beads impregnated with nanogoethite. Ecotoxicology and Environment Safety, 141, no. August 2016, pp. 226-234, 2017.

[17] Apha, Water Environment Federation, and American Water Works Association, Standard Methods for the Examination of Water and Wastewater (Part 1000-3000). Standard Methods for the Examination of Water and Wastewater, p. 733, 1999.

[18] NMX, Norma Mexicana Nmx-Aa-051-Scfi-2016 Análisis De Agua . -Medición De Metales Por Absorción Atómica En Aguas Naturales, Método De Prueba ( Cancela a La Nmx-Aa-051-Scfi-2001 ). Water Analysis - Measurement of Metals By Atomic Absorption in Natural Waters. 2016.

[19] Calero, J., Sánchez, Y.F., Tórrez, R., Hernann, E. \& López, K., Elaboración y caracterización de microcápsulas gastrorresistentes de diclofenac obtenidas por gelificación iónica. UNAN-León, Editor University, 1(2), pp. 27-30, 2008.

[20] Majumder, S., Raghuvanshi, S. \& Gupta, S., Application of a hybrid biofilter column for the removal of $\mathrm{Cr}(\mathrm{VI})$ from aqueous solution using an indigenous bacterial strain Pseudomonas taiwanensis. Bioremediation Journal, 20(1), pp. 10-23, 2016.

[21] Majumder, S., Gangadhar, G., Raghuvanshi, S. \& Gupta, S. Biofilter column for removal of divalent copper from aqueous solutions: Performance evaluation and kinetic modeling. Journal of Water Process Engineering, 6, pp. 136-143, 2015.

[22] Chakraborty, J., Mallick, S., Raj, R. \& Das, S., Functionalization of extracellular polymers of Pseudomonas aeruginosa N6P6 for synthesis of CdS nanoparticles and cadmium bioadsorption. Journal of Polymers and the Environment, 26(7), pp. 3097-3108, 2018.

[23] Beyenal, N.Y., Özbelge, T.A. \& Özbelge, H.Ö., Combined effects of Cu2+ and Zn2+ on activated sludge process. Water Research, 31(4), pp. 699-704, 1997.

[24] Gadd, G.M., Biosorption: Critical review of scientific rationale, environmental importance and significance for pollution treatment. Journal of Chemical Technology and Biotechnology, 84(1), pp. 13-28, 2009.

[25] Chojnacka, K. Biosorption and bioaccumulation - the prospects for practical applications. Environment International, 36(3), pp. 299-307, 2010.

[26] Muñoz, A.J. et al., Heavy metal tolerance of microorganisms isolated from wastewaters: Identification and evaluation of its potential for biosorption. Chemical Engineering Journal, 210, pp. 325-332, 2012. 
[27] Malik, A., Metal bioremediation through growing cells. Environment International, 30(2), pp. 261-278, 2004.

[28] Mangwani, N., Shukla, S.K., Rao, T.S. \& Das, S. Calcium-mediated modulation of Pseudomonas mendocina NR802 biofilm influences the phenanthrene degradation. Colloids Surfaces B Biointerfaces, 114, pp. 301-309, 2014.

[29] Verma, A., Kumar, S. \& Kumar, S. Biosorption of lead ions from the aqueous solution by Sargassum filipendula: Equilibrium and kinetic studies. Journal Environmental Chemical Engineering, 4(4), pp. 4587-4599, 2016.

[30] Loutseti, S., Danielidis, D. B., Economou-Amilli, A., Katsaros, C., Santas, R. \& Santas, P. The application of a micro-algal/bacterial biofilter for the detoxification of copper and cadmium metal wastes. Bioresource Technology, 100(7), pp. 2099-2105, 2009. 